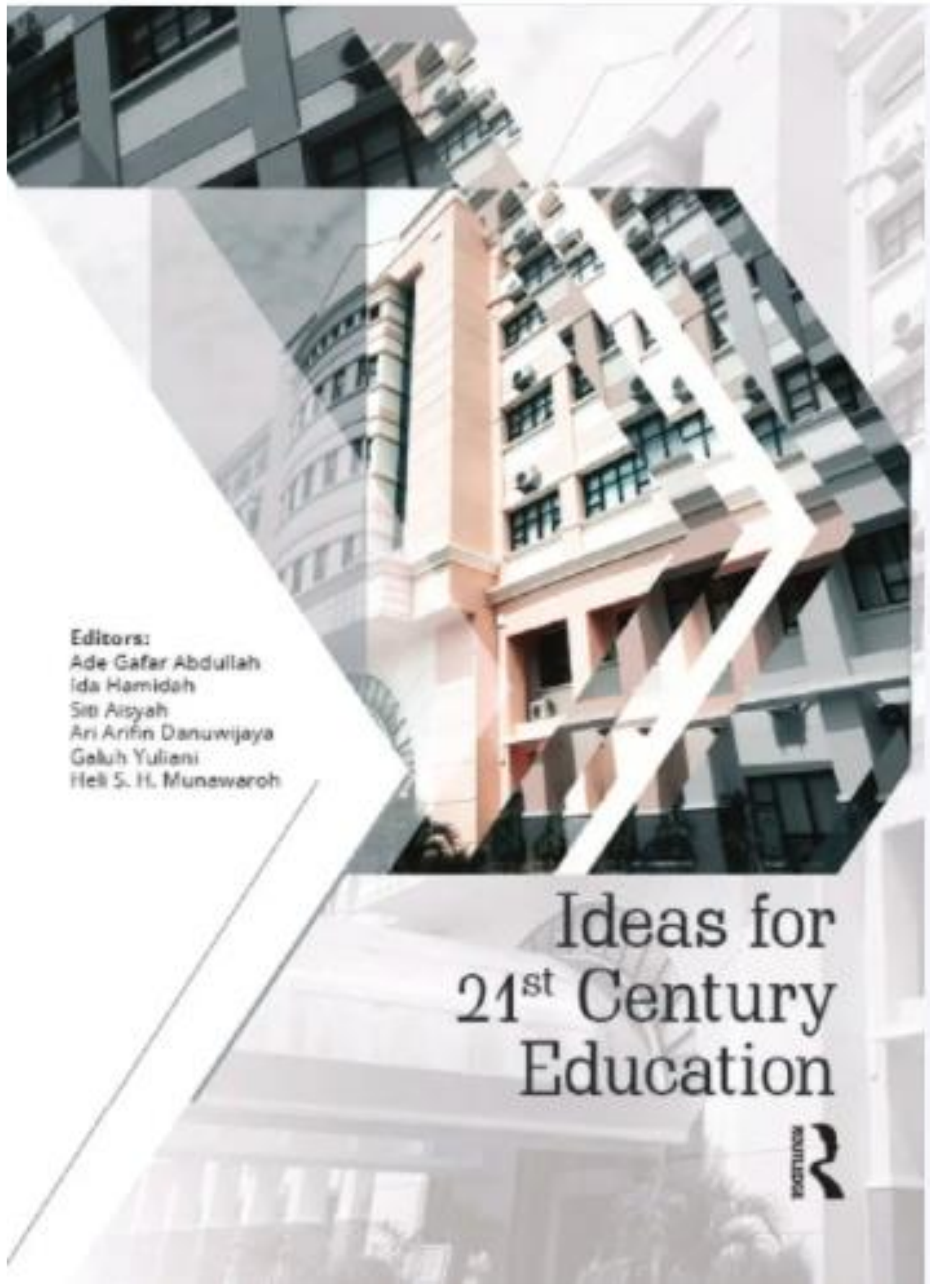


(4) Taylor \& Francis

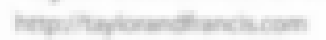


PAOCEEDINGS OF THE ABAN EDUCATION BMMPOSILM (HES 2016, $22 \mathrm{z}$ NONENEEF, BTE, BANDLNG, IHDONEEIA

\section{Ideas for 21 st Century Education}

Fillows

Ade Gafar Abdullah, Ida Hamidah, Siti Aisyah, Ari Arifin Danuwijaya, Galuh Yuliani \& Heli s.H. Munawaroh

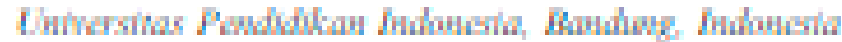

\section{Routledge \\ 8 1 Tylor Grancis Goup \\ LONDON AND NEW YORK}


Routledge is an imprint of the Taylor \& Francis Group, an informa business

Q 2017 Taylor \& Francis Group, London, UK

Typeset by V Publishing Solutions Pvt Ltd., Chennai, India

Printed and bound in Great Britain by CPI Group (UK) Ltd, Croydon, CR0 4 YY

All rights reserved. No part of this publication or the information contained herein may be reproduced, stored in a retrieval system, or transmitted in any form or by any means, electronic, mechanical, by photocopying, recording or otherwise, without written prior permission from the publisher.

Although all care is taken to ensure integrity and the quality of this publication and the information herein, no responsibility is assumed by the publishers nor the author for any damage to the property or persons as a result of operation or use of this publication and/or the information contained herein.

Published by: CRC Press/Balkema

Schipholweg 107C, 2316 XC Leiden, The Netherlands c-mail: Pub.NL@taylorandfrancis.com

www.crepress.com - www.taylorandfrancis.com

ISBN: 978-1-138-05343-4 (Hbk)

ISBN: 978-1-315-16657-5 (cBook) 


\section{Table of contents}

Preface

Acknowledgments

Organizing committees

Adult Education $(A D E$

Practicing critical thinking through extensive reading activities

Teaching learning sequence: Designing ionic bonding concept through model of educational reconstruction

E. Nursa'adah, L. Liliasari \& A. Mudzakir

Art Education $(A E D)$

Design-based research to explore Luk Keroncong as vocal technique exercise R. Milyartini

Event as a means to educate youth througl

D. R. Erlandia \& I. Gemihart

Stress at work and well-being: Study of stress level at work to improve employee well-being on Pertamina's operators with standard 'Pertamina Way' in Bandung

M. Batubara

Course Management (CMT)

Preceptors' perceptions of preceptorship at Surgical Care Room General Hospital Haji Adam Malik Medan

R.E. Nurhidayah, Y. Aryani \& C.T. Siregar

Curriculum, Research and Development (CRD

Improving the competences of vocational teachers: Graduate profile and learning outcomes of the agro-industry technology education program

M.N. Handayani

Authentic assessment analysis based on the KKNI curriculum in applied statistics learning V. Yustitia \& I.S. Wardani

The career competence profile of public elementary school students in Jakarta, Indonesia A. Tjalla \& H. Herdi

Educational Foundation (EDF)

Promoting undergraduate students' critical thinking skills in zoology vertebrate courses

S. Sa'adah, F. Sudargo \& T. Hidayat

Information processing capability in the concept of biodiversity

S. Rini, A. Rahmat, T. Hidayat, M. Gemilawati \& D. Firgiawan

The contribution of ereative thinking skills to students' creativity on enzyme kinetics

practical projects using local materials

D. K. Sari, A. Permanasari \& F.M.T. Supriyant

The effect of 'Everyone is a teacher here' strategy on students' results in geography

M. Meilia, G.N. Nindya \& Z.K. Habihah

Students' misconceptions on titration

H.R. Widarti, A. Permanasari \& S. Mulyani

Parent-adolescent conflict: Is there a difference of main sources between intergeneration? T.H. Dahlan, I.H. Misbach \& D.Z. Wyandini

Students' mental model profile of microorganism after the implementation of mental

model-based microbiology course

Y. Hamdiyati, F. Sudargo, S. Redjeki \& A. Fitrian

Building meaningful learning through coherence learning among mathematics, language and science lessons

1. Permanasari, T. Turmudi, V. Vismaia \& B. Rubin

The analysis of junior high schools' educational facilitics, infrastructure needs and location determination based on a social demand approach and geographical information system T. C. Kurniatum, E. Rosalin, L Somantri \& A. Setiyoko 


\title{
The enhancement of self-regulated learning and achievement of open distance learning students through online tutorials
}

\author{
U. Rahayu \\ Universitas Terbuka, Tangerang Selatan, Banten, Indonesia
}

A. Widodo \& S. Redjeki

Universitas Pendidikan Indonesia, Bandung, Indonesia

\begin{abstract}
Self-Regulated Learning (SRL) skill is an important aspect to be successful in studying at Open and Distance Learning (ODL). Independent learning skills can be introduced and be trained to students in various ways. The aim of this study was to discuss the benefits of SRL training in enhancing SRL skills and learning achievement of ODL students through an integration of learning strategies into the process of online tutorials. The design of this study used one group pretest and posttest design. Samples of this study were students who were taking the online tutorial of Biology Learning Strategies Course $(n=16)$. The results showed that the self-regulated learning ability of students before and after the treatment increased, though not significantly. However, self-monitoring aspect showed significantly increased. The students' achievement improved significantly. This study recommends that ODL tutors of online tutorials should train SRL skills to their students along with the online tutorial process so that the students' independent learning skills can improve gradually.
\end{abstract}

\section{INTRODUCTION}

Students of distance education are autonomous learners. It means that they have the authority in controlling their learning method and determining where to learn and how to achieve their goals (Moore 2005). The behavior of autonomous learners is strongly associated with the term of selfregulated learning (SRL). Distance education students should be able to take advantage of their authority when they study. The authorization can be carried out properly if they have skills in selfregulated learning. Zimmerman and Martinez-Pons (1990) emphasize that there is a correlation between student achievement and the use of self-regulated learning strategies (1990). Furthermore, according to Schunk and Ertmer (2000), students' independent learning skills can be improved through systematic interventions. Students' independent learning can be developed through the developing time management skills, understanding and summarizing the text, noting ideas, anticipating and writing test (Zimmermann et al. 1996); the use of tools matrix note taking and prompt self-monitoring (Kauffman et al. 2011), the use of time management tools (Puspitasari 2012), and etc. Along with advances in technology, the use of ICT-based networking in education, including distance education, have increased (Malik et al. 2005, Hu \& Gramling 2009), especially when they are used as students learning services (Fozdar \& Kumar 2007, Jung 2005).
Online tutorial began to be used as student learning services in distance education in Indonesia in 2009. It was developed with the intention to bridge the characteristic of distance education, which is "the physical separation between teacher and student". The online tutorial process is a mean of interaction between student, teacher, and student. Students' independent learning skills are possible to be trained through online tutorials (Rahayu et al. 2015). In this study, we will integrate learning strategies of SRL including cognitive and metacognitive strategies, such as self-monitoring, self-reflection, mind mapping, and question \& answer into the online tutorial process. Then, we will conduct a study that aims are to identify the difference of students' self-regulated learning skills and students' learning outcomes (pretest and posttest) between before and after online tutorials that integrate learning strategies.

\section{LITERATURE REVIEW}

Self-regulated learning (SRL) is a process that involves students in managing and organizing complex learning activities to achieve their academic goals (Zimmerman \& Schunk 2001). In line with these opinions, Pintrich (2000) states that SRL is an active and constructive process where learners specify learning goals and monitor, manage and control their cognition, motivation, and behavior to achieve the goal. 
Self-regulatory is a cyclical process which consists of three phases that are, forethought phase, performance or volitional control phase, and self-reflection phase (Zimmerman 2000). According to Shuy (2010), SRL consists of 3 aspects, those are, cognition, metacognition, and motivation. Cognition includes skills and habits in coding, remembering, recalling and critical thinking. Metacognition includes skills in which students are able to understand and monitor cognition process. Motivation includes the development of cognition and metacognition.

Each student has a different level of independent learning. It depends on their motivation to learn, the method used in the study, the utilization of existing performance, and the utilization of social resources and learning environment. Students whose level of independence of learning is low are much more likely to have lower educational achievement in schools (Zimmerman 2000).

\section{RESEARCH METHODS}

This research applied mixed methods. This study used one group pretest and posttest design. The independent variable of this research was the training of SRL integrated into the online tutorial. The dependent variables of the study were students' SRL skills and students' learning outcomes. The experiment was conducted during the academic year of 2016.

The populations of the study were the students who accessed the online tutorial of Biology Learning Strategy (BLS) courses in the first semester in 2016. The samples of the study were 16 students taking the online tutorial of BLS in Biology course and receiving the students' learning guide "Cerdas Strategy". The students' guide described how (1) to select and to use learning strategies, to manage and to motivate the learning process; (2) to use study time effectively; (3) to plan learning process realistically; (4) to set goals that can be achieved; (5) to plan learning targets accurately and with measurement; and (6) to plan learning objective specifically (Rahayu et al. 2016).

Data were collected using questionnaire, test, and observation sheets. Participants filled out 40 valid items modified MLSQ (motivation for Learning Strategy Questionnaire) in order to measure students' SRL skills; four-point Likert-type scale $(1=$ never; $2=$ rarely; $3=$ often; and $4=$ very often $)$, with the level of reliability $(r)=8.6$ at $\alpha=1 \%$. Participants filled out this questionnaire before and after the online tutorials integrating learning strategies. Participants took the online pretest and posttest to measure students' achievement, which was a standard test taken from the item bank. The online pretest was conducted before the online tutorial, and posttest was conducted after the online tutorial. During the online tutorial, participants were observed how often they had practiced self-monitoring (SM), self-reflection (SR), mind mapping (MM), and questions and answers (QA) writing. Besides that, participants also did three online tutorial tasks in order to measure concepts mastery. The collected data were analyzed using SPSS 17 for windows.

\section{RESULTS AND DISCUSSION}

We offered two primary sets of findings. The first set of analyses focused on the difference of students' SRL skills before and after the online tutorial, including 11 aspects of SRL. Then, it was correlated with the finding during the SRL training. Second, we analyzed the difference in the students' learning outcome before and after tutoring. It was correlated with the finding during the training of SRL and doing the tasks.

\subsection{The difference of mean score on students' $S R L$ skills before and after the online tutorial}

The data by means of students'SRL before and after online tutorial were normal $(p=0.200)$ and homogeneous $(p=.085)$. Then, the data was analyzed by t-test and the result was that the mean score of students' SRL before and after online tutorial were not significantly different $(p=0.165)$. It means that even though the mean score of SRL was increased (SRL' mean score before the online tutorial $=3.050$ and SRL' mean score after online tutorial $=3.184$ ), but the increase was not significant. The results of this study were consistent with other research. Darmayanti (2004) found that the intervention of learning strategies to open distance learning (ODL) students did not have a significant influence on the improvement of student' learning independence. Likewise, the results study of Puspitasari (2012), who found that the intervention time management and learning strategies did not significantly influence on the improvement of learning independence. Moreover, Barnard-Brak et al. (2010) suggested that the online lectures could not improve self-regulated learning. It seems to us that the SRL skills training given to the students might need more time. It is relevant to Darmayanti' study that student independent learning, increased after 5 years when students had implemented a learning strategy (Darmayanti 2012). Then, the data were analyzed further in order to see the difference of each SRL aspect. Summary of the p-value of mean difference of each SRL aspect, before and after online tutorial can be shown in Table 1 .

Table 1 showed that the mean score of self-monitoring aspect was significantly different. Self-monitoring is one of the processes that occurs in the performance phase. It is conducted during the learning process 
Table 1. Summary of p-value of mean score difference of each SRL aspect before and after online tutorial.

\begin{tabular}{clc}
\hline Dimension & Aspect & $P$ \\
\hline Motivation & Intrinsic \& extrinsic & 0.287 \\
& Self-efficacy & 0.519 \\
Learning & Goal setting & 0.910 \\
strategy & Strategic planning & .236 \\
& Scientific goal accomplishment & .452 \\
& Self-monitoring & $.00^{* *}$ \\
& Resource management & .452 \\
& Time management & .859 \\
& Regulation effort & .105 \\
& Self-evaluation & .207 \\
& Self -reaction & .094 \\
\hline
\end{tabular}

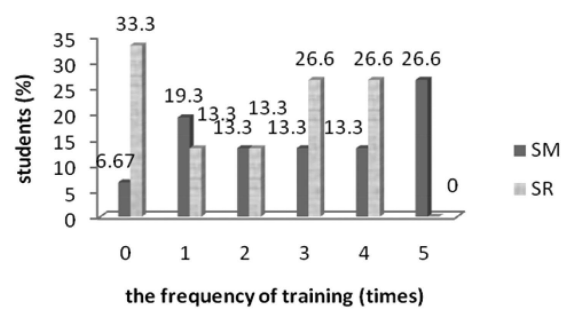

Figure 1. Frequency of student' self-regulated learning training for self-monitoring (SM) and content selfreflection (SR) at the online tutorial of BSL course.

(Schunk \& Ertmer 2005). Self-monitoring is a metacognitive skill which is necessary for students to control their learning process. According to Kaufman (2004), self-monitoring is an important aspect of the SRL because with this ability student gain feedback related to their own performance. Without selfmonitoring, effective control to the cognitive system might be very limited. In line with these results, Arsal (2009), Sungur \& Tekaya (2006) emphasized that there was a significant effect of the intervention on students' metacognitive ability.

During the online tutorial process, the students were trained metacognitive SRL (SM and SR) and cognitive SRL (MM and QA). There were $27 \%$ of students performed SM five times. Students did SM four times, three times and two times were $13 \%$. Students did not practice SM were $19 \%$.

In addition, during the online tutorial, $26.5 \%$ of students did the content of SR four times and three times. Students did the content of SR once and two times was $13.3 \%$. Students did not do SR were $33.3 \%$. Figure 1 showed the training activities of regulated learning regarding SM and content of SR.

\subsection{The differences of mean score on learning outcomes before and after the online tutorial}

The data of mean score of students' achievement before (pretest) and after online tutorial (posttest) were

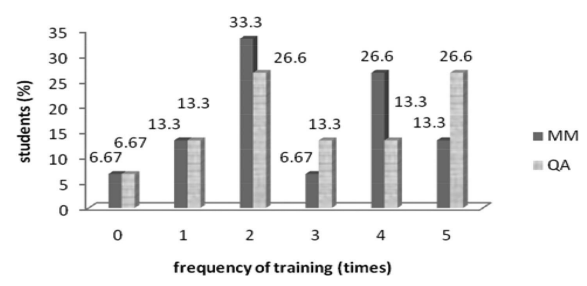

Figure 2. The frequency of student' self-regulated learning training for mind mapping and writing question and answer at the online tutorial of BSL course.

normal $(p=0.200)$ and homogeneous $(p=.0853)$. Then, the data was analyzed by t-test. The t-test result was that the mean score of students' achievement before and after online tutorial were significantly different $(\mathrm{p}=0.005)$. It means that there was an increase mean score of student achievement. The significant difference between pretest and posttest indicated that students' training on cognitive SRL, which were making mind mapping (MM) and writing question \& answer (Q \& A), had an effect on students' achievement.

During the online tutorial process, students' activities during the SRL training were; $13.3 \%$ of the students composed MM five times. Students composed MM four times were $26.6 \%$. Students composed MM three times were $67 \%$. Students composed MM two times were $33.3 \%$. The rest of the students $(13.3 \%)$ did not compose MM.

In addition, during the online tutorial process, $26.6 \%$ of students wrote Q \& A five times. Students wrote $\mathrm{Q} \& \mathrm{~A}$ four times and three times were $13 \%$. Students wrote Q \& A once were $27 \%$. The students did not practice Q \& A were $6.67 \%$ (see Figure 2). Then, when we analyzed further, the students who did the task for more SRL training had better posttest score than those who did not.

A significant difference between the pretest and posttest might also be the impact of metacognitive besides cognitive training undertaken by these students. The student who did more self-monitoring and self-reflection training, they arranged more mind mapping and question and answer. There was correlation between SM training and MM training (correlation coefficient $(r)=0.893, p<0.05$ with $\alpha=0.01$ ). There was correlation between SM training and QA training $(\mathrm{r}=0.866, \mathrm{p}<0.05$ with $\alpha=0.01$ ). There was correlation between SR training and $\mathrm{MM}(\mathrm{r}=0.808, \mathrm{p}<0.05$ with $\alpha=0.01)$. There was correlation between SM training and QA training $(\mathrm{r}=0.905, \mathrm{p}<0.05$ with $\alpha=0.01)$.

Training on cognitive process encourages the students to monitor activities during their learning. (Kaufman 2011). It might occur in this case. Training of MM and QA encouraged students to monitor and do self-reflection during their learning. Information which was obtained during monitoring, it 
was possibly used by students to adjust their learning strategy (Zimmerman \& Paulsen 1995). There was a synergism between metacognitive and cognitive training and its impact on learning outcome. It was in line with the result study of Kaufman (2011) dan Cazan's (2013). Cazan (2013) showed that the training combination of cognitive SRL and metacognitive strategies were able to improve learning outcomes. Kaufman (2011) showed that students who take notes using an online taking note matrix tool and self-monitoring prompt had better achievement than students who did not.

In addition, during the process of online tutorial, students did tasks 1,2 , and 3 . The average score achieved by the students at the first task was 83.79 , its second task was 92.5, and its third task was 81.4. So, the average score was about 86 . It showed that students' achievement was quite high. It indicated that tasks' score influenced on the post test score.

\section{CONCLUSIONS}

SRL training through online tutorial integrating learning strategy has significantly improved students' achievement and self-monitoring SRL. Therefore, SRL training should be continuously conducted by ODL instructor so that ODL students' SRL skills improve gradually.

\section{ACKNOWLEDGEMENTS}

The author would like to thank the Ministry of Research, Technology and Higher Education of Indonesia for the scholarship of BPPDN while doing a Post-Graduate education in Universitashu Pendidikan Indonesia.

\section{REFERENCES}

Arsal, Z. 2009. The effects of diaries on self-regulation strategies of preservice science teachers. International Journal of Environmental \& Science Education. 5(1): 85-103.

Barnard-Brak, L, Paton, V.O \& Lan, W.Y. 2010. Selfregulation across time of first-generation online learners. ALT-J. Research in Learning Technology. 18(1): 61-70.

Cazan, A.M. 2013. Teaching self-regulated learning strategies for psychology students. Procedia Social and Behavioral Sciences. 78: 743-747.

Darmayanti, T. 2004. Efektivitas intervensi keterampilan self-regulated learning dan keteladanan dalam meningkatkan kemampuan belajar mandiri dan prestasi belajar mahasiswa pendidikan jarak jauh' [effectivity intervention self-regulated learning skills and model to enhance independent learning and students' achievement at Distance Education]. Jurnal PJJ. 9(2): 68-82.
Fozdar, B.I. \& Kumar, L.S. 2007. Mobile learning \& student retention. International Review of Research in Open Distance Learning. 8(2): 1-18.

$\mathrm{Hu}$, H. \& Gramling, J. 2009. Learning strategies for success in a web course: A descriptive exploration. The Quarterly Review of Distance Education. 10(2): $123-134$

Jung. 2007. Changing faces of open and distance learning in Asia. International Review of Research in Open \& Distance Learning. 8(1): 1-6.

Kauffman, D.F. 2004. Self-regulated learning in webbased environments: instructional tools designed to facilitate cognitive strategy use, metacognitive processing, and motivational beliefs. J. Educational Computing Research. 30 (1\&2): 139-161.

Kauffman, D.F., Zhao, R. \& Yang, Y. 2011. Effect of online note taking formats and self-monitoring prompts on learning from online text: using technology to enhance self-regulated learning. Contemporary Educational Psychology. 36: 313-322.

Malik, N.A., Belawati, T. \& Baggaley. 2005. Framework of collaboration research and development on distance learning technology for Asia. Paper presented at the 19th AAOU Annual Conference Jakarta.

Moore, M.G. 2005. Learner autonomy: the second dimension of independent learning. Retrieved 21/10/2016, from http://192.107.92.31/Corsi_2005/bibliografia\%20elearning/learner_autonomy.pdf

Pintrich, P.R. 2000. The role of goal orientation in selfregulated learning. In $\mathrm{M}$. Boekarts, P. Pintrich, \& M. Zeidner (Eds.) Handbook of self-regulation (p. 451502). San Diego, CA: Academic Press.

Puspitasari, K. 2012. The effect of learning strategy intervention and study time management intervention on students' self-regulated learning, achievement, and course completion in a distance education learning environment. $\mathrm{Ph}$. D thesis. The Florida State University College Education.

Rahayu, U. Widodo, U., Redjeki, S. \& Darmayanti, T. 2015. Pembiasaan keterampilan self-regulated learning: mungkinkan melalui tutorial online. Paper presented at Temu Ilmiah Nasional Guru VII (TING VII), Universitas Terbuka, 25 th November.

Schunk, D.H. \& Ertmer, P.A. 2005. Self-regulation and academic learning: Self-efficacy enhancing intervention. In M. Boekarts, P. Pintrich, \& M. Zeidner (Eds.) Handbook of self-regulation (p. 631-646), San Diego, CA: Academic Press.

Sungur, S. \& Tekkaya, C. 2006. Effect of problem-based learning and traditional instruction on self-regulated learning. The Journal of Educational Research. 99(5): 307-319.

Zimmerman, B.J. \& Martinez-Pons, M. 1990. Students differences in self-regulated learning: relating grade, sex, and giftedness to self-efficacy and strategy use. Journal of Educational Psychology. 82:51-59.

Zimmerman, B.J. \& Schunk, D.H. 2001. Self-regulated learning and academic achievement: theoretical perspectives. Hisdale, N.J: Erbaum.

Zimmermann, B.J., Bonner, S. \& Kovach, R. 1996. Developing self-regulated learners: beyond achievement to self-efficacy. Washington, D.C: American Psychological Association. 